\title{
RAB7A Gene
}

National Cancer Institute

\section{Source}

National Cancer Institute. RAB7A Gene. NCI Thesaurus. Code C119631.

This gene is involved in the trafficking of endosomes and lysosomes. 